\title{
Ethnic Slurs as War Names in the Zimbabwean Liberation War
}

\author{
Lawrie A. Barnes \\ University of South Africa
}

Charles Pfukwa

Midlands State University

The Zimbabwean war of liberation raged from 1966 until 1979. During that time many combatants assumed (or were given) noms de guerre. From a collection of more than $\mathbf{4 8 0 0}$ of these war names we found that ethnic slurs comprised $9 \%$ of the total. One name in particular, Mabhunu, an adaptation of Boer, was especially common among ethnic slurs. The war names were seen to be important by the participants; they created images to be projected to the world at large or reflections constructed by outsiders.

\section{Introduction}

Zimbabwe is a landlocked country in southern Africa, bound to the south by South Africa, Mozambique to the east, Zambia to the north and Botswana to the west. With an area of 391,000 square kilometers it is slightly smaller than the state of California.

British rule in Zimbabwe was preceded by a mining concession in 1888, followed by settlers of European descent known as the "pioneer column." The pioneers asserted political control in 1890 followed by military control in 1896 after suppressing local resistance. They remained in power for almost a century and this created dissent and protest which at first was mild but intensified after the Second World War. It became active political resistance in the late 1950s and early 1960s as black nationalists demanded power (Bhebe 1999). Both sides adopted hardline positions which led to armed conflict.

The Unilateral Declaration of Independence by the Rhodesian Government in 1965 accelerated the conflict. The guerrilla war was spearheaded by two major Zimbabwean political parties, the ZAPU (Zimbabwe African Peoples Union) and the ZANU (Zimbabwe African

Names 55.4 (December 2007): 427-436

ISSN: 0027-7738

(C) 2007 by The American Name Society 


\section{Names 55.4 (December 2007)}

National Union). Between 1966 and 1970 raids were launched from Zambia which were confined to the western and northern border areas. Between 1972 and 1974 guerrilla armies launched sustained operations from northern Mozambique into the northeastern part of the country. Others launched operations from Zambia into western Zimbabwe. The détente exercise of 1975 was an effort by then U.S. Secretary of State Henry Kissinger and southern African leaders such as Kenneth Kaunda of Zambia and John Vorster of South Africa to bring peace. Zimbabwean nationalists were persuaded to negotiate some form of settlement. ZANU/ZANLA (the Zimbabwe African National Liberation Army and ZAPU/ZIPRA (the Zimbabwe People's Revolutionary Army) remained intransigent and the negotiations collapsed at the end of 1975 (Ellert 1989); 1976 to 1979 saw the final phase of the war (Beckett 2002; Ellert 1989). From 1976 onwards there were a series of abortive talks until a peace settlement and cease-fire were signed in December 1979.

The Oxford Dictionary of Current English (1964) defines a war name (nom de guerre) as a "[p]seudonym, sobriquet, assumed name under which a person fights, plays, etc." It is "closely related to nom de plume-also a pseudonym or title or initials or borrowed name under which one writes." Danner and Noël (1992) define nom de guerre as "a war name, formerly a pseudonym assumed by a French soldier entering military service; any fictitious name for a particular purpose." We will use nom de guerre and "war name" interchangeably.

In Shona, one of the major Zimbabwean languages, the nom de guerre has also been called zita re Chimurenga, from zita 'name' and re-Chimurenga 'of war'. Chimurenga itself is an epithet derived from Shona as a codename describing any form of uprising and can be traced back to the first wars of resistance in 1893 and 1896.

The term "ethnic slur" was coined by sociologist Irving Allen (1983; 1990) in his studies of derogatory names used in American communities. Allen wrote "Words are weapons; and 'hurling' epithets is a universal trait of hostile intergroup relations" $(1990,9)$. The Zimbabwean war also had its ethnic slurs. Ethnic slurs were part of the psychological arsenal of the guerrillas. Herbert (1999) calls them "friction names" and they are a valuable chronicle of race relations and conflict in a community. 
As we shall see below Mabhunu proved to be a major ethnic slur in the Zimbabwean war. Mabhunu is a linguistic modification of Boer, a term which is found in a number of European languages where it means simply 'farmer' or 'peasant'. The word was brought to southern Africa in 1652 by Dutch settlers who established themselves in Cape Town. For the next 150 years they moved into the interior and became Afrikaners who spoke Afrikaans. British rule at the Cape in 1806 forced them to move inland in what became known as the Great Trek. At this point a new meaning was added to Boer and it became synonymous with voortrekker 'pioneer'. The voortrekkers established the Orange Free State in 1854 and the Transvaal Republic in 1857 as independent Boer republics. There was conflict with Nguni people from Zululand over space for settlement and agriculture. From these interactions Boer found its way into local languages where it was modified into amabhunu, makaburu, amaburu and other forms and where it acquired derogatory connotations.

Branford and Branford (1991) note seven meanings of the word Boer: it can refer to early Dutch settlers; it means a farmer; it refers to an Afrikaner fighter in the Anglo-Boer war of 1899-1902; it can mean an Afrikaner, especially in political contexts; it is prison slang and tsotsitaal (local slang) for the police or prison warder; for blacks especially along the border it can mean a member of the South African Army; Afrikaners in a democratic South Africa see themselves as Boers.

Meanings 5 and 6 refer to uniformed forces regardless of color and this is the sense it was used in Zimbabwe especially given that the South African army and police fought the guerrillas in Zimbabwe during different periods of Chimurenga. It was associated with oppression and repression. However, not all whites were "Boers;" there were some who were referred to as Varungu, Mangezi, or Makiwa, meaning 'white' (Godwin 1996). These are more neutral terms and were usually reserved for missionaries, tourists and all those who were seen in a positive light by the black population, especially the whites of English descent. In Zimbabwe today murungu is Shona slang for anybody who is wealthy or a customer, especially in the informal economy (Mawadza 2000). 


\section{Sources and Functions of Ethnic Names}

Of the many definitions of ethnicity, Joseph (2004) and Edwards (1985) adopt a linguistic perspective. Allen $(1983 ; 1990)$ and Dundes (1983) treat ethnicity from an anthropological point of view. This literature has several common themes that are of interest to the current study. Ethnic identity is a paradox in that it is at once an act of discrimination but simultaneously a binding force for the group (Joseph 2004,120 ). Some group identities express racial prejudice and the solidarity here can be seen as negative. On the other hand a group can come together under an ethnic banner to preserve threatened extinction (Joseph 2004; Holland 1990).

The paradox of collective identities can be linked with another, which involves intended identities and perceived identities. According to Joseph (2004) the ethnic label expresses itself at two levels: how the group perceives itself and expresses solidarity and how the group perceives its adversaries. These two aspects manifest themselves clearly in the ethnic slurs discussed here. This study puts more emphasis on how the group perceives its adversaries. Also, ethnic labeling is a reciprocal process. Guerrillas called the whites Boers and in turn the whites called the guerrillas terrorists, terrs, gooks, wogs, and magandanga 'murderers'. (Godwin and Hancock 1995; Lan 1985).

Naming is an important site in the struggle for power and the person who names another or names a place controls social, political and psychological space (Squire 1996; Carter 1987; Gilmore 1982). In giving the enemy a name guerrillas were claiming psychological power over their adversaries. These are often hostile, derogatory and insulting as observed by Allen (1990) when he captures the undercurrents of hostility in the phrase "verbal aggression." Bright's (2000) study on the social implications of the word squaw is another example of such verbal aggression.

In southern Africa there is a general consensus that Mabhunu has racial and derogatory connotations. There are recurrent words and phrases in the squaw controversy that are found in the discourses on Boer and Mabhunu: race, ethnicity, pejorative, derogatory, and culture contact.

Besides Pongweni (1983) and Pfukwa (2003) very little work has been done by Zimbabweans on ethnic slurs in an armed conflict. Herbert 
(1999) identifies interesting parallels between the Zimbabwean and South African ethnic slurs in war names. South Africans like Turner (1997), de Klerk (1998), Haron (1999), and Prabhakaran (1998a; 1998b) have worked on nicknames in South Africa from an ethnic perspective but none of these have focused particularly on noms de guerre.

From the available literature there appears to be a general consensus that war names are used to conceal identities (Diament 1986; Herbert 1999; Pfukwa 2003). Names that people call each other are sometimes powerful indicators of social relations (Allen 1983; Herbert 1999). Besides being an expression of resistance and protest the names were part of an ideological effort to engage an enemy hitherto thought to be invincible and they blurred regional identities. The renaming process in the guerrilla war was an important part of a wider struggle to develop a new social and ideological orientation.

The names presented below are from a longer list, which is part of an ongoing research project on Zimbabwean war names and are drawn from several sources. The first is The Herald, a local daily that for three days in August 1983 published lists of ZANLA guerrillas who died in the war between January 1966 and December 1980. This list was later consolidated and published in the form of a book called Fallen Heroes, which is the second source. The book has many editing problems but it is still a valuable source of data on Zimbabwean noms de guerre. The third source is fiction on the Zimbabwean war. The names are taken from Gumbo's Guerrilla Snuff (1995), Chinodya's Harvest of Thorns (1989) and Samupindi's Pawns (1989). The fourth scurce is the historical text which records noms de guerre as part of historical research. Some of these have lists that are attached as appendices (Pongweni 1983; Tungamirai 1995). In other instances the names appear within the text (Bhebe 1999; Lan 1985; Moorcraft and MacLaughlin 1998; Nhongo-Simbanegavi 2000).

\section{Results}

The total number of names collected was 4,835 . The number of ethnic slurs on this general roll was 439 , just under $10 \%$ of the entire corpus. Table 1 shows the names we considered, by category. The categories were determined after consulting Koopman (2002), Neethling (1994), and de Klerk (2002). 


\section{Names 55.4 (December 2007)}

Table 1. Names from the Zimbabwean War

\begin{tabular}{lll}
\hline Name Type & N & \% (Rounded) \\
\hline English Given Names & 1467 & 30 \\
Full Shona Names & 1310 & 27 \\
Names From Popular Culture & 514 & 11 \\
Ethnic Slurs & 439 & 9 \\
Flora and Fauna & 252 & 6 \\
Female Names & 203 & 4 \\
Names From Other Languages & 178 & 4 \\
Martial Names & 162 & 3 \\
Ideological Names & 139 & 3 \\
Other Names & 141 & 3 \\
\hline
\end{tabular}

Hondo Muhondo 'war in war' was the most common name with slightly over $8 \%$ of all the names collected. This was a popular choice that was a reflection of the state of war that the country was in and taking up such a name was a constant reminder of the armed conflict. The second most frequent name was Mabhunu 'Boers' with just over 7\% of all names collected. This name was part of many noms de guerre, as listed below. Chimurenga 'uprising' was the third most frequent name, comprising $6.8 \%$ of all the names collected. These were followed by Tichatonga 'we shall rule', which instilled confidence in its bearers who were sure that one day they would rule the country, Magorira, Zimbabwe and Nyika. Magorira is an adaptation of the English word guerrillas, modified to suit Shona orthography while retaining its semantic properties. Zimbabwe and Nyika looked forward to the nation that would be renamed Zimbabwe. The names were used both as first names and as surnames.

The ethnic slurs were classified into three groups in order to facilitate analysis. In the first group are names that were very aggressive and openly taunted the enemy (72\%); the second contained milder slurs $(16 \%)$ and the third had slurs with English names or were creative phrases (12\%). 
The Openly Aggressive Subgroup

Names in this subgroup openly derided and challenged the enemy: Mabhunu Varoyi Muchapera 'Boers, you are wizards, we shall wipe you out'. (In most African communities witchcraft was a very serious offence punishable by death)

Ridzai Mabhunu 'shoot the Boers'

Tinhai Mabhunu 'chase the Boers'

Tsikai Mabhunu 'crush the Boers'

Bayai Mabhunu 'stab the Boers'

Sherai Mabhunu 'shell the Boers'

Pfurai Mabhunu 'shoot the Boers'

Pondai Mabhunu 'kill the Boers'

Urayai Mabhunu 'kill the Boers'

Rovai Mabhunu 'hit the Boers'

Shingirirai Kurova Mabhunu 'persevere in hitting the Boers'

Donorai Mabhunu 'hit the Boers'

Chatsemura Mabhunu 'he who splits the Boers'

Pururai Mabhunu 'shred the Boers'

Svuurai Mabhunu 'strip the Boers'

Gwazai Mabhunu 'mow down the Boers'

Pisai Mabhunu 'incinerate the Boers'

Chakukura Mabhunu 'that which sweeps away the Boers'

Kwetsai Mabhunu 'clean up the Boers'

Dzasukwa Gezai Mabhunu 'they [the guns] have been cleaned to wash away the Boers'

Zondai Mabhunu 'hate the Boers'

Tukai Mabhunu 'berate the Boers'

Pfutseki Mabhunu 'go away Boers' (Pfutseki is a Shona adaptation of the Afrikaans word voetsek 'go away', which has been transferred to a number of southern African languages. It has become a swear word and to be addressed with pfutseki is a deep insult.)

Mabhunu Muchaparara 'You Boers, you shall be destroyed'

Hamutikuriri Mabhunu 'You will not defeat us, you Boers' 


\section{Names 55.4 (December 2007)}

Muchandiona Mabhunu 'You shall see my wrath, you Boers'

Tichapedzarana Mabhunu 'We will take this to the very end, you Boers'.

The Milder Slurs

These carried less venom and often included names that were common in the Shona community:

Handichatambi Nemabhunu 'I no longer play with the Boers'

Matute Dzungu Remabhunu 'He who takes away the folly of the Boers' Maidei Mabhunu 'Boers, what did you want?'

Takawira Mabhunu 'We fell onto the Boers'

Zvichapera Mabhunu 'It shall end, you Boers'

Slurs with English Names and Innovative Phrases

William Chidyamabhunu 'that which eats the Boers'

Gibson Mabhunu

Joseph Mabhunu

Pack and Go

Boer Chopper

Killmore Mabhunu

Crashmore Mabhunu.

\section{Conclusion}

Beyond concealing identities, ethnic slurs became another weapon in engaging an enemy who had built up a myth of invincibility. Renaming became part of the wider process of dismantling an ideological fortress that protected colonial power. Ethnic slurs became powerful statements which filled the discursive spaces once held by western names and they became aggressive acts that sought to erase the entire ideology and culture of Rhodesia. The following points were also noted:

Self-naming was common. Naming the self was an act of defiance given that the guerrillas ignored the formal processes of consultation and related ceremonies that each culture follows in the naming process (see de Klerk 1998; Kimenyi 1989).

The names were temporary; they would flourish for a time after which they would fall into oblivion as the circumstances around them changed. Such names are set to satisfy certain functions and when those functions are no longer apparent they either fall away or are refashioned. 
Identities were socially constructed. Some of these could be images that the namer sought to project and others could be perceptions or views constructed by other people or other groups.

\section{References}

Allen, I. L.1983. The Language of Ethnic Conflict. New York. Columbia Univ. P. .1990. Unkind Words: Ethnic labeling from Redskin to WASP. New York: Bergin and Garvey.

Bhebe, N. 1999. The Zapu and Zanu Guerrilla Warfare and the Evangelical Lutheran Church. Gweru: Mambo P.

Branford, J., and W. Branford. 1991. A Dictionary Of South African English. Cape Town: Oxford Univ. P.

Bright, W. 2000. "The Sociolinguistics of the 'S-Word:' Squaw in American Place Names." Names 48: 207-16.

Carter, P. 1987. The Road to Botany Bay. London: Faber and Faber.

Chinodya, S. 1989. Harvest of Thorns. Harare: Baobab.

Danner, H. G., and R. Noël. 1992. A Thesarus of Word Roots of the English Language. London: Univ. P. of America.

de Klerk, V. 1998. "Nicknaming Across Cultures: Borrowing and Other Linguistic Tricks." Nomina Africana 12: 1-18. . 2002. "Xhosa Nicknames for Whites: A Double-Edged Sword." Nomina Africana 16: 146-63.

and B. Bosch. 1995. "Naming in Two Cultures: English and Xhosa Practices." Nomina Africana 9: 68-87.

Diament, H. 1986. "Dangerous Christenings: The Case of Code Names of French Secret Agents in the Second World War." Names 34:34-47.

Dundes, A. 1983. "Defining Identity through Folklore." In A. JacobsonWidding, ed., Identity: Personal and Socio-Cultural. Uppsala: Almquist and Wissel.

Edwards, J. 1985. Language and Identity. London: Basil Blackwell.

Ellert, H. 1989. The Rhodesian Front War, Counter-Insurgency Guerrilla War: 1962-1980. Gweru: Mambo P.

Godwin, P., and I. Hancock. 1995. Rhodesians Never Die. Harare: Baobab.

Gilmore, D. H. 1982. "Some Notes on Community Nicknaming." Man 17: 686-700. 


\section{Names 55.4 (December 2007)}

Gumbo, M. 1996. Guerrilla Snuff. Harare: Baobab.

Haron, M. 1999. "Naming Peoples: The formation of the South African Muslim Identity." Nomina Africana 13: 19-31.

Herbert, R. K. 1999. "Personal Names as Social Protest: The Status of African Political Names." Names 47: 109-24.

Holland. T. J., Jr. 1990. "The Many Faces of Nicknames." Names 38: 255-73.

Joseph, J. 2004. Language and Identity. London: Macmillan.

Kimenyi, A. 1989. Kinyarwanda and Kirundi Names. Lewiston: Edwin Mellen P.

Koopman, A. 2002. Zulu Names. Scottsville: Univ. of Natal P.

Lan, D. 1985. Guns and Rain. London: James Currey.

Mawadza, A. 2000. "Harare Shona Slang: a Linguistic Study." Zambezia XXVII: 93-101.

Moorcraft, P. L., and P. McLaughlin. 1982. Chimuremga-The war in Rhodesia 1965-1980. Marshaltown: Sigma/Collins.

Nhongo-Simbanengavi, J. 2000. For Better or for Worse: Women and ZANLA in Zimbabwe's Liberation Struggle. Harare: Weaver.

Pfukwa, C. 2003. "Onomastic Innovation in Zimbabwean noms de guerre." Language Matters 34: 13-25.

Pongweni, A. J. C. 1983. What's in a Name? A Study of Shona Nomenclature. Gweru: Mambo P.

Prabhakaran, V. 1998a. "Exploring Hindu Telegu Surnames." Nomina Africana 12: 49-68.

. 1998b. "An Introduction to Indian Hindu Surnames." Nomina Africana 12: 33-49.

Samupindi, C. 1989. Pawns. Harare: Baobab.

Squire, C. J. 1996. "Returning to Paradise through Naming: The Incantation of Names in B. Breyten Breytenbach's Return to Paradise." Nomina Africana 10: 79-97.

Tungamirai, J. 1995. "Recruitment to ZANLA: Building up a War Machine." In Bhebhe, N., and T. Ranger, eds, Soldiers in Zimbabwe's Liberation War. Harare: UZ Publications.

Turner, N. S. 1997. "Onomastic Caricatures: Names Given to Employers and Co-workers by Black Employees." Nomina Africana 11: 50-66. 